\title{
Investor Types and Company Performance through Private Placements Basing on State-Owned and -Controlled Listed Companies
}

\author{
Li Jiaojiao ${ }^{1,2} \&$ Qu Zenglong ${ }^{2}$ \\ ${ }^{1}$ School of Business, Southwest University of Political Science \& Law, China \\ ${ }^{2}$ Boston University, Massachusetts, United States \\ Correspondence: Li Jiaojiao, School of Business, Southwest University of Political Science \& Law, Chongqing \\ 401120, China. E-mail: cqljj727@163.com
}

Received: August 18, 2019

doi:10.5539/ijbm.v14n11p250
Accepted: September 25, 2019

Online Published: October 28, 2019

\begin{abstract}
Theoretical and empirical analyses of listed companies owned and controlled by the state making private placement transactions during 2006 and 2013 were carried out to measure the short-term announcement effect of strategic and financial investors' subscription for new shares in listed companies owned and controlled by the state on corporate governance and long-run performance of these listed companies. It was found that private placements had a positive influence on the performance of a state-owned and -controlled listed company as they brought new institutional investors to the company; strategic investors who subscribed for new shares in a state-owned and -controlled listed company have appeared to cause an announcement effect greater than financial investors; state-owned and -controlled listed companies that attracted strategic investors with private placements showed a higher level of corporate governance and better long-run performance in comparison to those launching private placements to financial investors only. This study reveals the differences between strategic and financial investors in their influences on short-term announcement effect, corporate governance, and long-run performance of a state-owned and -controlled listed company when they enter into private placement transactions with the company. These findings provide new perspectives on the economic consequences arising from the involvement of external institutional investors in private placements of state-owned and -controlled listed companies, which, to a certain extent, facilitate the decision-making process in private placement transactions and promote the mixed-ownership reform.
\end{abstract}

Keywords: State-owned and -controlled listed companies, strategic investors, financial investors, private placement

\section{Introduction}

Considering the rapid development of institutional investors since 1980s, it has been heatedly discussed whether institutional investors impact a company's corporate governance and performance. Previous studies at home and abroad represented two radically different views on this topic. "Shareholder activists" hold that institutional investors have great economic strength and proven information gathering capability, which allow them to supervise a company's management and improve its performance. Taken together, shareholder activists consider institutional investors as an active factor in corporate governance (Parrino et al., 2003; Ferreira \& Matos, 2008). In contrast, those who argue the opposite view that larger market fluctuations occur when institutional investors, who appear to lack the foresight, make transactions frequently and simply "vote with their feet" by selling their shares (Edmans, 2009; Edmans \& Manso, 2011; Hirschman, 1970). These opinions indicate two distinctly different perspectives on the institutional investors' willingness and capability to engage in corporate governance and how they perform on the task, which depends on the investment environment, investment restrictions, and the proportion of shareholdings (Yang et al., 2012). Unlike listed companies in the UK and the US, most listed companies in China are highly centralized. Furthermore, listed companies owned and controlled by the state generally show a severe lack of supervision by the controlling shareholders over the managers. As a result, they are confronted with agency problems between the controlling and the minority shareholders, as well as between the shareholders and the managers. These characteristics of China's state-owned and -controlled listed companies may account for the distinctly different impact of institutional investors on corporate governance compared to the conclusions drawn by researchers from Western countries. Private placements play an important role in the 
mixed-ownership reform undertaken by these state-owned and -controlled listed companies. As the primary target of a private placement, institutional investors are not allowed to sell new shares until at least 12 months (i.e., lockup period) after the date of subscription; for the sales of new shares after the lockup period, there are specified time and amount limits (Note 1). To gain a better understanding of the institutional investors' role in corporate governance and the effect of the mixed-ownership reform on the listed companies owned and controlled by the state, it is worth studying how institutional investors can improve a state-owned and -controlled listed company's corporate governance and performance by subscribing for new shares.

Despite the prevailing opinion in favor of the positive relationship between the institutional investors and a company's corporate governance and performance, the impacts of different types of institutional investors may largely vary. Liu and Peng (2006), Mccahery et al. (2016), as well as Li and Yan (2017) argued that long-term institutional investors, compared to the short-term ones, were more motivated and capable of corporate governance, which effectively reduced the management's potentially opportunistic behavior and improved the investee's performance. External institutional investors can be classified as financial and strategic investors according to their purposes of participating in private placements. A strategic investor refers to a legal entity that maintains a close business relationship with an issuing company and intends to hold the company's shares as a long-term investment. A financial investor entails an investor who enters into private placement transactions with a company mainly based on the hope for financial gains in a short term with a low shareholding percentage. Besides, according to the China Securities Regulatory Commission (CSRC), financial and strategic investors must abide by different rules and regulations on the lockup periods in private placement transactions. Are these characteristics associated with the differences between financial and strategic investors in their willingness and capability of corporate governance? If so, can these characteristics reflect how differently strategic and financial investors affect a company's short-term announcement effect and long-term performance by subscribing its new shares through private placement programs.

Through theoretical and empirical analysis, this study answered the questions above using the governance effect of institutional investors and the principal-agent theory, and thereby revealed that domestic state-owned and -controlled listed companies might implement the mixed-ownership reform by private placements to external institutional investors. By answering the questions, this study provides a theoretical basis for securities regulators on improving the private placement system that applies to state-owned and -controlled listed companies in China and to accelerate the mixed-ownership reform by introducing institutional investors to these state-owned and -controlled listed companies.

The main contributions of this study are two-fold: (1) Despite the existing studies on the role of institutional investors in corporate governance and its economic consequences, little research has been done on the impact of institutional investors on corporate governance in light of private placement transactions with state-owned and -controlled listed companies, as well as the economic consequences associated with their subscription for new shares of the listed companies; this study provides a new perspective on the role of institutional investors in corporate governance by discussing whether a listed company owned and controlled by the state can fill the gap left by the lack of supervision from controlling shareholders via private placements to institutional investors and improve its performance by engaging institutional investors in corporate governance.

(2) There are considerable discussions on the economic consequences brought by private placements of listed companies; also, scholars have carried out comparative analyses on the short-term announcement effect and long-term performance associated with the related and non-related shareholders' subscriptions for new shares of listed companies through private placements (Srinivasan \& Krishnamurthy et al., 2005; Zhang \& Zhao, 2012). Yet, little research has been conducted to explore the economic consequences of the state-owned and -controlled listed companies conducting private placement transactions with strategic and financial investors in regard to different investment purposes. In short, this study extends the research on economic consequences arising from private placements of listed companies and presents an in-depth analysis of the relationship between institutional investor heterogeneity and company performance.

\section{Literatures Review}

Institutional investors have gained impressive development since the late 1900s and become an indispensable part of the securities markets in developed and emerging economies. As shareholder activism emerged, the academic community began to pay closer attention to the role of institutional investors in corporate governance. However, researchers still hold mixed opinions about the effect of institutional investors on a listed company's corporate governance. Based on the hypothesis of effective supervision, institutional investors actively engage in a company's corporate governance in diverse ways to reduce the agency problems between shareholders and 
managers and to raise shareholder value (Shleifer \& Vishny, 1986; Aggarwal et al., 2011; Callen \& Fang, 2013). Typically, they pursue a proxy voting by making active use of their voting rights (Mccahery et al., 2016); bring forward shareholder proposals (Gillan \& Stark, 2000); draw the board of directors and the management into private conversations (Mccahery et al., 2016; Chen, 2017) and disclose the shortlist of target companies subject to the corporate governance on designated media at regular intervals (Parrino et al., 2003); delegate board representatives to participate in the governance of the board of directors, criticize managers publicly, and supervise managers through a hostile takeover (David \& Kochhar,1996). The view of inefficient supervision includes the conflict-of-interest hypothesis and the strategic-alignment hypothesis. According to the conflict-of-interest hypothesis, institutional investors are swing traders that "vote with their feet". Therefore, the limited supervision from these investors is not an active factor in improving corporate governance but a trigger for short-term behaviors of the investees (Holderness \& Sheehan, 1988; Useem et al., 1993). The strategic-alignment hypothesis holds that an institutional investor and the management of a company tend to form an alliance after the cost-benefit analysis to gain benefits at the expense of other external shareholders' interests (Pound, 1988).

No consistent conclusion has been drawn because an institutional investor's willingness and capability to engage in corporate governance and the outcome of its participation is mainly affected by such factors as the source of fund, investment restrictions, and the investor's purpose and preferences (Yang et al., 2012). Ferreira and Matos (2008), as well as Aggarwal et al. (2011) further categorized institutional investors into two groups, i.e., dependent and independent institutional investors, based on their relationships with the investees. Also, they pointed out that independent institutional investors were more interested in corporate governance, and as they were independent of the investees, the management was under effective supervision; in contrast, dependent institutional investors seemed to play a submissive role without making a notable improvement in corporate governance. Almazan et al. (2005), Gillan and Starks (2007), and Mao et al. (2012) divided institutional investors into active and passive institutional investors with respect to the difference in the allocated amount of supervision costs. They believed that active institutional investors could notably improve the senior management's pay-for-performance sensitivity while passive institutional investors play an insignificant role in this aspect. It is widely held that a higher shareholding percentage and a longer investment term committed by an institutional investor means more effective supervision on the major shareholders and managers. Koh (2007), Li and Yan (2017), as well as Borochin and Yang (2017) separated institutional investors into long and short-term investors according to the duration of their past investment behaviors, and found that the long-term institutional investors were more motivated and capable of corporate governance, which effectively reduced the management's potentially opportunistic behavior and improved the investee's performance. This is because long-term institutional investors aim to generate governance gains in portfolio companies whereas short-term institutional investors focus on trading gains (Chen et al., 2007). Additionally, domestic researchers also analyzed the role of strategic and financial investors in corporate governance. In some studies, the introduction of overseas strategic investors into domestic listed companies was regarded as an effective approach to improve the corporate governance mechanism of the listed companies (Chen et al. 2011; Zhang and Song, 2010; Hasan and Xie, 2012), alleviate the agency problems facing domestic commercial banks, increase the effectiveness of senior management compensation/incentive plans (Chen et al., 2014) and improve company performance (Megginson and Netter, 2001; Zhang et al, 2014). In contrast, Ge and Zhang (2014) argued that only strategic investors played a positive role in governing family companies.

For listed companies in China, institutional investors are major targets of private placements. As private placements of new shares thrive across the country, institutional investors' subscription for new shares of the listed companies has drawn special attention. In a listed company, controlling shareholders have a great say in deciding the pricing base day, issuance object, issuing price, and the number of shares. Therefore, prior literature largely suggested tunneling and propping in private placement transactions between select investors (including institutional investors) and controlling shareholders of domestic listed companies (Zhu et al., 2008). Through empirical analysis, Zhang (2010) found that a listed company might direct its financial resources to related shareholders through earnings management before private placements. Other studies showed that controlling shareholders might transfer company assets and profits to related shareholders by injecting bad assets into the company (Ji et al., 2010, Zhang and Li, 2010), as well as Li and Gan (2015) discovered that controlling shareholders might conduct price manipulation for the benefit of related shareholders when injecting assets to their company through private placements. Also, Zhang (2017) revealed that controlling shareholders might manipulate the issuing price of new shares in the process of R\&D expenditure accounting to supply related shareholders with inappropriate benefits. Yet, it should be noted that all these studies analyzed the influence of institutional investors from a "passive" perspective. In other words, the researchers only focused on those institutional investors and controlling shareholders who collaborated to seek personal gain but ignored the fact that private placements of 
domestic listed companies have a relatively long lockup period and that institutional investors may exert a positive influence on corporate governance.

\section{Theoretical Analysis and Research Hypotheses}

The relationship between institutional investors and company performance remains controversial mainly because institutional investors, as shareholders of their portfolio companies, may generate a short-term investment profit by "voting with their feet". Since state-owned and -controlled listed companies basically make private placement transactions with institutional investors who are strictly forbidden to sell their holdings until at least 12 months after the subscription, the institutional investors tend to participate in the corporate governance and improve company performance by "voting with their hands" during the lockup period. Among the highly centralized listed companies in China, there is often a severe lack of supervision in the state-owned and -controlled listed companies by the controlling shareholders over the managers, making them beset with agency problems between the controlling and the minority shareholders, as well as between the shareholders and the managers. In other words, agency costs are typically high in these state-owned and -controlled listed companies. To reduce agency costs as well as to improve corporate governance and company performance, state-owned and -controlled listed companies may issue new shares to the institutional investors through private placements. On this basis, state-owned and -controlled listed companies that enter into private placement transactions with institutional investors outperform those without private placements.

Through the above analysis, the following hypothesis can be established:

Hypothesis $_{H I}$ : With other criteria being kept equal, state-owned and -controlled listed companies that attract institutional investors using private placement programs will have better performance than those not using the private placements.

No consistent conclusion has been drawn because an institutional investor's willingness and capability to engage in corporate governance, and also because the outcome of its participation is mainly affected by such factors as the source of fund, investment restrictions, and the investor's purpose and preferences (Yang et al., 2012). According to the purposes of new shares subscription through private placements, institutional investors can be classified into strategic and financial investors. Financial investors look forward to achieving financial gains in a short term by selling their portfolios. Contrary to the financial investors, strategic investors have a higher shareholding percentage and a longer lockup period, and they attach more importance to an investee's long-term strategic development and planning. With a higher shareholding percentage and a longer lockup period, strategic investors are more motivated and capable than financial investors in terms of engaging in and improving the corporate governance of listed companies. Comparing strategic and financial investors, the former is expected to outperform the latter in improving corporate governance by subscribing for new shares in the state-owned and -controlled listed companies through private placements. The news of a strategic investor participating in a private placement of a state-owned and -controlled listed company indicates the investor's confidence in the company's future development, as well as its participation in corporate governance to realize massive improvement in company performance. In this case, the listed company is to experience a surge in its share price as more investors are attracted to the private placement. Therefore, the investment strategies of strategic investors are often regarded as important guidelines for individual and other small investors. According to the signaling theory, the introduction of strategic investors into a state-owned and -controlled listed company through private placements gives other investors an optimistic outlook on the company's future development, such as an enormous growth potential and a higher company value, thereby leading to the "herd behavior" among investors ( $\mathrm{Li} \& \mathrm{Li}, 2008$ ) and the ballooning of the company's share price. Collectively, strategic investors bring a positive announcement effect on the company's share price. Janney and Folta (2006) illustrated the influence of strategic investors on the private placement-related short-term announcement effect based on the information asymmetry theory. Specifically, they regarded a listed company's private placement to strategic investors as an effective measure to raise information transparency and boost market confidence in the company's share value, thereby attracting more prospects and raising the company's market value. According to the signaling theory, when strategic investors participate in a listed company's private placement program, they become more motivated and capable of corporate governance, which sends positive signals to the market and encourages more investors to subscribe for the company's shares, further implying the generation of a relatively strong announcement effect that lifts the share value in a short term. Considering the fact that financial investors are less willing or motivated to play a governance role after subscribing for the investee's new shares, and would rather focus on generating financial gain in a short term, if only financial investors are involved in a private placement, other investors may receive no positive signals from their subscription. This is possibly the reason underlying the insignificant short-term announcement effect of financial investors' participation in private placements. On top of these, the short-term announcement effect may 
also be mitigated by the leakage of internal and private information before the announcement, which is a typical phenomenon in the domestic securities market. In conclusion, the short-term announcement effect associated with private placement transactions between the strategic investors and a state-owned and -controlled listed company is greater than that brought by financial investors. Considering that strategic investors are more motivated and capable of playing a governance role in the company and substantially reduce the agency cost, they outperform financial investors in improving the company's long-term performance through corporate governance.

Through the above analysis, the following hypotheses can be made:

Hypothesis $_{\mathrm{H} 2}$ : With other criteria being kept equal, state-owned and -controlled listed companies enlisting private placement transactions with strategic investors will make a greater improvement in corporate governance than those that involve only financial investors.

Hypothesis $_{H 3}$ : With other things being kept equal, state-owned and -controlled listed companies that attract strategic investors using private placements will surpass other companies targeting at financial investors only in terms of short-term announcement effect and long-term performance.

\section{Empirical Research Design}

(1) Sampling and data sources

In this study, state-owned and -controlled listed companies that launched private placement programs between 2006 and 2013 were analyzed to explore the influence of institutional investors on the announcement effect and the companies' corporate governance and long-term performance. Relevant data concerning the involvement of strategic and financial investors in private placements of state-owned and -controlled listed companies were gathered manually from the "Information Disclosure" section given in the annual reports between 2006 and 2013, while the financial data came from Wind and CSMAR databases. Because the analysis of the companies' long-term performance affected by strategic and financial investors required close observation for three years, and considering that the performance data after 2016 were not available during the study, the sampling period was ended in 2013. The exclusion criteria are as follows: a. Listed companies in the financial sector. Listed finance companies should be excluded as they differ from other listed companies in terms of business scope and capital structure. b. ST or *ST listed companies. c. Listed companies without complete financial data or having abnormal data. Having incorporated the exclusion criteria, a total of 352 observed values were eligible for this study. Stata14.0 was used for data processing and analysis.

(2) Variable selections and metrics

a. Announcement effect: cumulative abnormal return (CAR)

Cumulative abnormal return (CAR) can be defined as the sum of all abnormal returns from a private placement. In this study, CAR was calculated using a market-adjusted model. $C A R_{i}$ represents the cumulative excess return for sample $i$ in the estimation window $T$. Considering the leakage phenomenon in China's capital market, the CAR estimation window falls between $[-10,20]$. The calculation formula is as follows:

$$
\begin{gathered}
C A R_{i}=\sum_{t=-10}^{20} A R_{i t}, \\
A R_{i t}=R_{i t}-R_{m t}=\frac{P_{i t}-P_{i t-1}}{P_{i t-1}}-\frac{P_{m t}-P_{m t-1}}{P_{m t-1}}
\end{gathered}
$$

where $R_{i t}$ denotes the return for sample $i$ on day $t ; R_{m t}$ stands for the return on the stock market index on

day $t ; P_{i t}$ means the closing price of sample $i$ on day $t ; P_{i t-1}$ represents the closing price of sample $i$ on day

$t-1 ; P_{m t}$ expresses the closing index value on day $t ; P_{m t-1}$ indicates the closing index value on day $t-1$.

In this study, the announcement date of a private placement plan was an event point for the CAR calculation.

b. Corporate governance index (CGI)

Principal component analysis (PCA), first proposed by Hotelling in 1933, is a method of multivariate statistical analysis which seeks the low-dimensional approximations to high-dimensional data by observing the internal structure of an index system based on the idea of dimensionality reduction, with the low-dimensional 
approximations independent of each other and preserving as much variance as possible (>85\%). PCA has the following advantages: definitive weights that represent the internal relations between different indexes obtained from data analysis will not be affected by subjective factors while all comprehensive indexes (principal components) are independent of each other, which reduces the possibility of information overlapping and ensures that the evaluation and analytical results are objective and determinable. Based on the methods used by Bai (2005) as well as Zhang and Liao (2010), an index system was set up for PCA. Twelve indicators regarding equity structure and shareholders' equity, the board of directors and board governance, and the management governance were selected as the indices that reflected a company's level of corporate governance. The descriptions and definitions of these indicators are shown in Table 1. The characteristic value, contribution ratio, and cumulative contribution ratio of each correlation matrix were calculated while the number of principal components was also determined. As shown in Table 2, the PCA yields eight principal components with a cumulative contribution ratio of $85 \%$ and above. Furthermore, a load matrix of the principal components is displayed in Table 3. From the load matrix, the coefficient of each principal component was determined, and the CGI value was calculated using the weight coefficients.

Table 1 . The CGI system

\begin{tabular}{|c|c|c|}
\hline CGI & Description & Definition \\
\hline \multirow{7}{*}{$\begin{array}{l}\text { Equity structure and } \\
\text { shareholders' equity }\end{array}$} & Funds occupied by the & (Other receivables - other payables) / total assets \\
\hline & controlling shareholders & The number of annual general meeting(s) \\
\hline & The number of shareholders' & The shareholding percentage of the largest shareholder \\
\hline & meeting(s) & The sum of the shareholding percentages of the second to the tenth \\
\hline & Ownership concentration & largest shareholders/shareholding percentage of the larges \\
\hline & Ownership checks and & shareholder \\
\hline & balances & \\
\hline \multirow{10}{*}{$\begin{array}{l}\text { Board of directors and } \\
\text { board governance }\end{array}$} & The scale of the board of & The number of directors \\
\hline & directors & The number of annual board meeting(s) \\
\hline & $\begin{array}{l}\text { The number of board } \\
\text { meeting(s) }\end{array}$ & $\begin{array}{l}\text { e.g., audit committee, compensation and appraisal committee } \\
\text { strategy committee, nomination committee }\end{array}$ \\
\hline & The number of specialized & The ratio of independent director(s) to all directors of the board \\
\hline & committee(s) & $\mathrm{CEO}$ duality $=1 ;$ non-CEO duality $=0$ \\
\hline & The proportion & The shareholding percentage of all directors \\
\hline & independent director(s) & \\
\hline & Duality & \\
\hline & The shareholding percentage & \\
\hline & of the board of directors & \\
\hline \multirow{3}{*}{$\begin{array}{l}\text { Management } \\
\text { governance }\end{array}$} & Senior management & The total compensation for the top three executives \\
\hline & compensation & The shareholding percentage of all managers \\
\hline & $\begin{array}{l}\text { Shareholding percentage of } \\
\text { the management }\end{array}$ & \\
\hline
\end{tabular}

Table 2. The correlation matrix: characteristic values, contribution ratios, and cumulative contribution ratios

\begin{tabular}{llll}
\hline Principal component & Characteristic value & Contribution ratio & Cumulative contribution ratio \\
\hline Comp1 & 2.54027 & 0.2117 & 0.2117 \\
Comp2 & 1.50798 & 0.1257 & 0.3374 \\
Comp3 & 1.41126 & 0.1176 & 0.455 \\
Comp4 & 1.20738 & 0.1006 & 0.5556 \\
Comp5 & 1.07601 & 0.0897 & 0.6452 \\
Comp6 & 0.968116 & 0.0807 & 0.7259 \\
Comp7 & 0.925853 & 0.0772 & 0.8031 \\
Comp8 & 0.8112 & 0.0676 & 0.8707 \\
\hline
\end{tabular}


Table 3. The load matrix of principal components

\begin{tabular}{lllllllll}
\hline & Comp1 & Comp2 & Comp3 & Comp4 & Comp5 & Comp6 & Comp7 & Comp8 \\
\hline Comp1 & 0.5441 & -0.3899 & 0.0335 & -0.1436 & 0.1351 & 0.2211 & 0.04 & 0.0616 \\
Comp2 & -0.2409 & -0.4686 & 0.2536 & 0.4078 & 0.0563 & -0.2502 & 0.269 & -0.0458 \\
Comp3 & -0.0294 & 0.0865 & 0.5989 & -0.1919 & -0.2508 & 0.0633 & 0.1755 & 0.0007 \\
Comp4 & 0.298 & 0.3396 & 0.1838 & 0.4659 & 0.0466 & 0.0336 & 0.2248 & -0.2461 \\
Comp5 & -0.1182 & -0.0266 & -0.0388 & -0.1225 & 0.0572 & 0.4721 & 0.5716 & -0.5272 \\
Comp6 & -0.0812 & 0.0421 & 0.0577 & 0.099 & 0.7003 & 0.1986 & 0.2756 & 0.5581 \\
Comp7 & 0.0371 & 0.0285 & -0.1299 & 0.1016 & -0.6294 & 0.1559 & 0.4224 & 0.5723 \\
Comp8 & 0.175 & 0.0811 & -0.0762 & 0.0456 & 0.0622 & -0.7279 & 0.3854 & -0.0573 \\
\hline
\end{tabular}

c. Long-term performance: buy-and-hold abnormal return (BHAR)

This study calculated the equally weighted buy-and-hold abnormal return (BHAR) for a select company based on the stock yield of 36 months following its private placement to measure the company's performance in the long run. The calculation formula is as follows:

$$
B H A R_{i}=\prod_{t=1}^{36}\left(1+R_{i t, m}\right)-\prod_{t=1}^{36}\left(1+R_{m t, m}\right)
$$

Where $R_{i t, m}$ means the monthly return for sample $i$ in month $t$ after a private placement; $R_{m t, m}$ represents the return on the stock market index in month $t$ following the private placement.

In this study, the announcement date of a private placement plan was an event point for BHAR calculation.

d. Dummy variable (Dum): whether a select company has private placements or not

Propensity score matching (PSM) was employed in this study to match the state-owned and -controlled listed companies with private placements and those without private placements on the basis of industry, year, leverage ratio, the shareholding percentage of the largest shareholder, corporate growth, and company size, thereby controlling the impact of other noises on the analytical results. After the PSM, if a state-owned and -controlled listed company has no private placements, the $d$ value is set as 0 ; for the corresponding company that introduces institutional investors using private placements, the $d$ value equals to 1 .

e. Control variables

According to prior studies on the involvement of institutional investors in private placements, the following indicators served as the control variables in this study: new shares issuance scale (Issuance), leverage ratio (Lev), shareholding percentage of the largest shareholder (Top1), corporate growth (Grow), company size (Lnsize), industry (Industry) and year (Year). Definitions of these variables are given in Table 4. 
Table 4. Variable definitions

\begin{tabular}{|c|c|c|c|}
\hline Category & Description & Symbol & Definition \\
\hline \multirow{3}{*}{$\begin{array}{l}\text { Explained } \\
\text { variables }\end{array}$} & $\begin{array}{l}\text { Short-term } \\
\text { announcement effect }\end{array}$ & CAR & $\begin{array}{l}\text { Cumulative abnormal return for a sample in the window }[-10 \text {, } \\
\text { 20]. }\end{array}$ \\
\hline & $\begin{array}{l}\text { Corporate } \\
\text { governance }\end{array}$ & CGI & $\begin{array}{l}\text { Based on a principal component analysis of an index system } \\
\text { designed for this study, the highest principal component score } \\
\text { is the corporate governance index. }\end{array}$ \\
\hline & $\begin{array}{l}\text { Long-term } \\
\text { performance }\end{array}$ & BHAR & $\begin{array}{l}\text { Equally weighted buy-and-hold abnormal return on a monthly } \\
\text { basis, with } i \text { equals to } 36 \text { months. }\end{array}$ \\
\hline \multirow{2}{*}{$\begin{array}{l}\text { Explanatory } \\
\text { variables }\end{array}$} & $\begin{array}{l}\text { Whether a select } \\
\text { company has private } \\
\text { placements or not }\end{array}$ & Dum & $\begin{array}{l}\text { After the PSM, if a state-owned and -controlled listed } \\
\text { company has no private placements, the } \mathrm{d} \text { value is set as } 0 \text {; for } \\
\text { the corresponding company that introduces institutional } \\
\text { investors using private placements, the } \mathrm{d} \text { value equals to } 1 \text {. }\end{array}$ \\
\hline & $\begin{array}{l}\text { Type of institutional } \\
\text { investor }\end{array}$ & StraInv & $\begin{array}{l}\text { If strategic investors participate in the private placements of a } \\
\text { state-owned and -controlled listed company, the StraInv value } \\
\text { is } 1 \text {; if only financial investors are involved, the StraInv value } \\
\text { is } 0 \text {. }\end{array}$ \\
\hline \multirow{7}{*}{$\begin{array}{l}\text { Control } \\
\text { variables }\end{array}$} & $\begin{array}{l}\text { New shares issuance } \\
\text { scale }\end{array}$ & Issuance & The fund raised from a private placement. \\
\hline & Leverage ratio & Lev & $\begin{array}{l}\text { The ratio of total liabilities to total assets at the end of a } \\
\text { financial year. }\end{array}$ \\
\hline & $\begin{array}{l}\text { Shareholding } \\
\text { percentage of the } \\
\text { largest shareholder }\end{array}$ & Top1 & $\begin{array}{l}\text { The ratio of the shareholding of the largest shareholder to total } \\
\text { shares. }\end{array}$ \\
\hline & Corporate growth & Grow & $\begin{array}{l}\text { Revenue growth represents a company's growth, i.e., (annual } \\
\text { operating revenue - operating revenue of the previous year) } / \\
\text { operating revenue of the previous year. }\end{array}$ \\
\hline & Company size & Lnsize & $\begin{array}{l}\text { The Napierian logarithm of total assets at the end of reporting } \\
\text { period. }\end{array}$ \\
\hline & Year & Year & $\begin{array}{l}\text { A variable that controls the impact associated with the } \\
\text { difference between years. }\end{array}$ \\
\hline & Industry & Industry & $\begin{array}{l}\text { A variable that controls the impact related to the difference } \\
\text { between industries. }\end{array}$ \\
\hline
\end{tabular}

(3) Empirical model

To examine Hypothesis ${ }_{H I}$, that is, measuring the impact of introducing institutional investors into a state-owned and -controlled listed company through private placements on the company's performance, model (1) was constructed as follows:

$$
\begin{aligned}
& \text { BHAR }_{t}=\beta_{o}+\beta_{1} \text { Dum }_{t}+\beta_{2} \text { Lev }_{t-1}+\beta_{3} \text { Top }_{t-1}+\beta_{4} \text { Grow }_{t-1} \\
& +\beta_{5} \text { Lnsize }_{t-1}+\beta_{6} \text { Industry }+\beta_{7} \text { Year }+\varepsilon
\end{aligned}
$$

To examine Hypothesis ${ }_{H 2}$, that is, comparing the impacts of strategic and financial investors on a company's short-term announcement effect, model (2) was built as follows:

$$
\begin{aligned}
& \text { CAR }_{t}=\beta_{o}+\beta_{1} \text { StraInv }_{t}+\beta_{2} \text { Issuance }_{t-1}+\beta_{3} \text { Lev }_{t-1}+\beta_{4} \text { Top }_{t-1}+\beta_{5} \text { Grow }_{t-1} \\
& +\beta_{6} \text { Lnsize }_{t-1}+\beta_{7} \text { Industry }+\beta_{8} \text { Year }+\mathcal{E}
\end{aligned}
$$

To examine Hypothesis ${ }_{H 3}$, that is, comparing the impacts of strategic and financial investors on corporate governance and long-term performance, models (3) and (4) were given as follows:

$$
\begin{aligned}
& \text { CGI }_{t}=\beta_{o}+\beta_{1} \text { StraInv }_{t}+\beta_{2} \text { Issuance }_{t-1}+\beta_{3} \text { Lev }_{t-1}+\beta_{4} \text { Top }_{t-1}+\beta_{5} \text { Grow }_{t-1} \\
& +\beta_{6} \text { Lnsize }_{t-1}+\beta_{7} \text { Industry }+\beta_{8} \text { Year }+\varepsilon
\end{aligned}
$$




$$
\begin{aligned}
& \text { BHAR }_{t}=\beta_{o}+\beta_{1} \text { StraInv }_{t}+\beta_{2} \text { Issuance }_{t-1}+\beta_{3} \text { Lev }_{t-1}+\beta_{4} \text { Top }_{t-1}+\beta_{5} \text { Grow }_{t-1} \\
& +\beta_{6} \text { Lnsize }_{t-1}+\beta_{7} \text { Industry }+\beta_{8} \text { Year }+\varepsilon
\end{aligned}
$$

\section{Empirical Results and Analysis}

(1) Analysis of descriptive statistics

Table 5. The descriptive statistics

\begin{tabular}{lllllll}
\hline \multirow{2}{*}{ variables } & $\begin{array}{l}\text { Number } \\
\text { samples }\end{array}$ & Mean & SD & Minimum value & Median & Maximum value \\
\hline CAR & 352 & 0.012 & 0.282 & -0.813 & -0.033 & 1.561 \\
CGI & 352 & -0.351 & 0.150 & -0.439 & -0.397 & 1.147 \\
BHAR & 352 & 0.123 & 0.547 & -1.184 & 0.068 & 2.341 \\
StraInv & 352 & 0.139 & 0.347 & 0.000 & 0.000 & 1.000 \\
Issuance & 352 & 20.755 & 0.999 & 18.048 & 20.663 & 23.582 \\
Lev & 352 & 0.576 & 0.192 & 0.013 & 0.599 & 1.399 \\
Top1 & 352 & 0.394 & 0.149 & 0.068 & 0.398 & 0.837 \\
Grow & 352 & 0.330 & 0.645 & -0.725 & 0.196 & 5.171 \\
Lnsize & 352 & 22.086 & 1.322 & 18.072 & 21.881 & 26.074 \\
\hline
\end{tabular}

As shown in Table 5, the descriptive statistics of the main variables indicate the distribution of the samples' observed values. To be specific, the mean, median, minimum and maximum values of CAR are respectively $0.012,-0.033,-0.813$, and 1.561, indicating a significant difference in the companies' short-term announcement effect. CGI's mean and median are -0.351 and -0.397 , meaning that the samples largely have a relatively low level of corporate governance. BHAR's mean and median are 0.123 and 0.068 , which reflect improvement in long-term performance; yet, with the maximum and minimum values varying markedly, a significant difference in long-term performance is observed. With StraInv's minimum value being zero, only financial investors are involved in the private placements of some state-owned and -controlled listed companies; similarly, StraInv's maximum value indicates that both strategic and financial investors participate in the private placements of some state-owned and -controlled listed companies. StraInv's mean value is 0.139 , suggesting that $13.9 \%$ of the samples have enlisted private placement transactions with strategic investors. In terms of the issuance scale, the maximum and minimum values vary slightly, and the SD reaches 0.999 . These indicate an insignificant difference between the samples in the new shares issuance size. Lev's mean value is greater than 0.5 , and thus there is still room for improvement in the samples' solvency. Top1's mean value is 0.394 and the median is 0.398 , suggesting that the highly centralized equity structure still plays a dominant role in the domestic listed companies. Generally, the wide gap between the maximum and minimum Grow values indicates a considerable difference between the samples in revenue growth. Lnsize's SD is 1.322, which shows the narrow fluctuations in a sample's total assets at the end of the reporting period.

(2) Correlation analysis

\begin{tabular}{|c|c|c|c|c|c|c|c|c|c|}
\hline & CAR & CGI & BHAR & StraInv & Issuance & Lev & Top1 & Grow & Lnsize \\
\hline CAR & 1.000 & & & & & & & & \\
\hline CGI & $0.112 * *$ & 1.000 & & & & & & & \\
\hline BHAR & 0.015 & $0.088 *$ & 1.000 & & & & & & \\
\hline StraInv & $0.393 * * *$ & $0.147 * * *$ & $0.117^{* *}$ & 1.000 & & & & & \\
\hline Issuance & 0.005 & -0.003 & $-0.216^{* * *}$ & 0.004 & 1.000 & & & & \\
\hline Lev & $-0.140 * * *$ & $-0.151 * * *$ & $-0.096^{*}$ & -0.070 & $0.190 * * *$ & 1.000 & & & \\
\hline Top1 & -0.083 & $-0.187 * * *$ & -0.012 & -0.031 & $0.185^{* * *}$ & 0.047 & 1.000 & & \\
\hline Grow & 0.025 & -0.021 & -0.056 & -0.007 & -0.012 & $0.102 *$ & 0.088 & 1.000 & \\
\hline Lnsize & 0.006 & -0.085 & $-0.195^{* * *}$ & 0.027 & $0.615^{* * *}$ & $0.392 * * *$ & $0.266^{* * *}$ & 0.037 & 1.000 \\
\hline
\end{tabular}

Table 6. The correlation matrix

Notes. ${ }^{*}, *$, and $* * *$ represent the significance levels of $0.01,0.05$, and 0.1 , respectively. 
The relationship between dependent and independent variables was tested by running Pearson's correlation analysis, and the correlations between the main variables are shown in Table 6 . According to the table, the coefficient of correlation between CAR and StraInv is 0.393 when strategic investors are involved in private placements, and the coefficient is statistically significant at the 0.1 level, indicating that strategic investors have a positive influence on improving the announcement effect of their investees. This is a source of support for Hypothesis $_{H 3}$. As for CGI and StraInv, the correlation coefficient is 0.147 , which is statistically significant at the 0.1 level. This suggests that a state-owned and -controlled listed company may issue new shares to strategic investors to improve its corporate governance. For BHAR and StraInv, if strategic investors are involved in the private placements of state-owned and -controlled listed companies, the correlation coefficient is 0.117 , which is statistically significant at the 0.05 level. In other words, strategic investors who participate in a state-owned and -controlled listed company's private placements play an active role in improving the company's long-term performance. This preliminarily validates Hypothesis ${ }_{H 4}$. Besides, the absolute values of all correlation coefficients between the explanatory and control variables are lower than 0.4 , except the coefficient of correlation between Lnsize and Issuance (0.615). Therefore, no multicollinearity was observed in the regression model constructed for this study.

(3) Empirical results

Table 7. The influence of private placement transactions with institutional investors on state-owned and -controlled listed companies

\begin{tabular}{|c|c|}
\hline & BHAR \\
\hline Dum & $\begin{array}{l}0.635^{* * *} \\
(9.82)\end{array}$ \\
\hline Lev & $\begin{array}{l}-0.059 \\
(-1.01)\end{array}$ \\
\hline Top1 & $\begin{array}{l}0.067 \\
(0.45)\end{array}$ \\
\hline Grow & $\begin{array}{l}-0.016^{* * *} \\
(-2.84)\end{array}$ \\
\hline Lnsize & $\begin{array}{l}-0.046 * * * \\
(-2.96)\end{array}$ \\
\hline cons & $\begin{array}{l}0.600 * \\
(1.77)\end{array}$ \\
\hline Industry & Control \\
\hline Year & Control \\
\hline $\mathrm{N}$ & 642 \\
\hline $\mathrm{F}$ & 7.96 \\
\hline Adj R-squared & 0.303 \\
\hline
\end{tabular}

Notes. t-value is enclosed in brackets. $* * * * *$, and * represent the significance levels of $0.01,0.05$, and 0.1 , respectively.

PSM-based regression results are as shown in Table 7. The adjusted R-squared is 0.303 , indicating that the regression model is interpretable. With the F-value of 7.96 and the corresponding p-value of 0.000 , the overall regression effect is satisfactory. Dum's regression coefficient is 0.635 , and is statistically significant at the 0.1 level. This indicates that the state-owned and -controlled listed companies enlisting private placement transactions with institutional investors deliver better performance than those without private placement plans. As PSM has effectively diminished the adverse effect brought by interference factors, to some extent, the endogeneity problem is solved and Hypothesis ${ }_{H I}$ is validated. 
Table 8. The influence of strategic and financial investors participating in private placements of state-owned and -controlled listed companies

\begin{tabular}{llll}
\hline & $(1)$ & $(2)$ & $(3)$ \\
& CAR & CGI & BHAR \\
\hline StraInv & $0.299^{* * *}$ & $0.044^{*}$ & $0.166^{*}$ \\
& $(7.02)$ & $(1.85)$ & $(1.95)$ \\
Issuance & -0.011 & 0.010 & -0.054 \\
& $(-0.60)$ & $(0.96)$ & $(-1.42)$ \\
Lev & $-0.213^{* *}$ & $-0.085^{*}$ & 0.035 \\
& $(-2.40)$ & $(-1.72)$ & $(0.20)$ \\
Top1 & -0.153 & $-0.161^{* * *}$ & 0.207 \\
& $(-1.54)$ & $(-2.92)$ & $(1.04)$ \\
Grow & 0.018 & 0.000 & -0.042 \\
& $(0.81)$ & $(0.01)$ & $(-0.94)$ \\
Lnsize & 0.021 & -0.006 & $-0.059^{*}$ \\
cons & $(1.31)$ & $(-0.71)$ & $(-1.86)$ \\
Industry & -0.224 & $-0.367^{*}$ & $2.454^{* * *}$ \\
Year & $(-0.65)$ & $(-1.92)$ & $(3.57)$ \\
$\mathrm{N}$ & Control & Control & Control \\
F & Control & Control & Control \\
Adj R-squared & 352 & 352 & 352 \\
\hline v val & 3.24 & 2.10 & 2.38 \\
& 0.165 & 0.089 & 0.109 \\
\hline
\end{tabular}

Notes. value is enclosed in brackets. ${ }^{* *}, * *$, and $*$ represent the significance levels of $0.01,0.05$, and 0.1 , respectively.

The regression results of models (2), (3), and (4) are as shown in Table 8. With the adjusted R-squared values of $0.165,0.089$ and 0.109 , these models show good interpretability. The F-values are 3.24, 2.10 and 2.38, respectively, while all p-values are 0.000 , revealing a general positive regression effect.

Column (1) of Table 8 shows the test results concerning how strategic investors involved in private placements of a state-owned and -controlled listed company affect the announcement effect. The StraInv regression coefficient is 0.299 , and it is significant at the 0.01 level. This indicates that a company issuing new shares to strategic investors shows a greater short-term announcement effect than that engaging financial investors only in its private placements. On this basis, Hypothesis $\mathrm{H}_{2}$ is validated.

Column (2) of Table 8 presents the test results regarding how strategic investors involved in private placements of a state-owned and -controlled listed company affect its corporate governance. The StraInv regression coefficient is 0.044 , and is statistically significant at the 0.1 level. Therefore, if strategic investors are involved in the private placements of a state-owned and -controlled listed company, a higher level of corporate governance is expected in comparison to other companies inviting financial investors only for its private placements. In addition, strategic investors' participation in private placements appears to improve corporate governance significantly. Column (3) of Table 8 presents the test results on how strategic investors involved in private placements of a state-owned and -controlled listed company affect its long-term performance. The StraInv regression coefficient is 0.166 , and is statistically significant at the 0.1 level, meaning that if strategic investors are involved in the private placements of a state-owned and -controlled listed company, the company outperforms other companies that offers private placements to financial investors only for the long run. In other words, strategic investors can remarkably improve a state-owned and -controlled listed company's long-term performance by participating in its private placement programs. This proves Hypothesis ${ }_{H 3}$ in this study.

(4) Robustness test

The robustness of the above multiple regression results was tested by replacing BHAR, Top1, and Grow with the return on equity (ROE), the shareholding percentage of the top five shareholders (Top5), and the total asset growth (AGrow), respectively. The results from another multiple regression analysis following the same steps were basically consistent with the previous conclusions. Therefore, these conclusions are regarded as robust. 


\section{Conclusions and Policy Recommendations}

This study investigated China's state-owned and -controlled listed companies that engaged in private placements from 2006 and 2013 based on theoretical and empirical analyses to identify the influences of strategic and financial investors on the short-term announcement effect, corporate governance, and long-term performance by subscribing new shares of these companies through private placements and clarify the differences between these institutional investors. It was found that with other things being equal, a state-owned and -controlled listed company experiences a positive influence on its performance after enlisting private placement transactions with institutional investors compared to other companies without private placement plans; further, strategic investors surpasses financial investors in improving a state-owned and -controlled listed company's short-term announcement effect, corporate governance and long-term performance by subscribing for its new shares through private placements. This study plays an important role in helping researchers gain a better understanding of different types of institutional investors, the motivation behind their subscription for a state-owned and -controlled listed company's new shares through private placements, and their influences on the company's short-term announcement effect, corporate governance, and long-term performance. To a certain degree, it provides guidance for state-owned and -controlled listed companies to decide on the target investors of private placements, promotes the mixed-ownership reform on state-owned and -controlled listed enterprises, as well as deepens the state-owned-enterprise reform.

On the basis of theoretical and empirical analyses, the following recommendations are put forward to guarantee rational private placements by state-owned and -controlled listed companies, take a shift smoothly towards mixed ownership and promote the internationalization of China's capital market. First, institutional investors should be introduced into state-owned and -controlled listed companies through private placements to fill the gap left by the lack of supervision from the controlling shareholders and further improve the corporate governance structure applied to state-owned and -controlled listed companies. From this, it can be seen that private placements act as an effective measure to implement the mixed-ownership reform. Second, when issuing new shares to institutional investors, to maximize the positive effect of long-term investment on corporate governance, state-owned and -controlled listed companies should attract as many strategic investors and other long-term-focused investors as possible to their private placements. Third, state-owned and -controlled listed companies should learn from other listed companies in overseas capital markets, where mature institutional investors play a role in corporate governance, and combine their successful experience with the actual condition to improve the relevant laws and regulations, as well as the market condition, and to ease the restrictions on institutional investors' participation in corporate governance, thereby making full use of institutional investors in the improvement of corporate governance.

The limitations of manual data collection in this study should be noted as bias was unavoidable during the collection of private placement data from the annual reports and private placement announcements of the listed companies.

\section{Acknowledgements}

This paper are supported by the SWUPL foundation(2015XZZD-04), Chongqing Social Science Foundation(2016YBGL118).

\section{References}

Chen, J. (2017). Institutional Investor Heterogeneity, Private Conversation and Corporate Governance. Graduate School of Chinese Academy of Social Science (Doctoral Dissertation).

Chen, W. Z., Hao, X. C., Shi, N. (2014). An Analysis on the Influence of Overseas Strategic Investors on Compensation Incentives for Senior Management of Commercial Banks Based on Data from Commercial Banks in China. Journal of Financial Research, 12, 117-132.

Ge, Y. S., \& Zhang, P. C. (2013). Resources Restriction of Family Business, Outside Investor and Contract Surplus. Nankai Business Review, 3, 57-68.

Han, Q., \& Wang, H. (2014). Insurance against the Responsibilities of Independent Directors, Institutional Investors and Corporate Governance. Nankai Business Review, 5, 54-62.

Li, J. J. (2016). Large Shareholder Control, Asset Injection of Directional Add-Issuance and Interest Supply. Press of Southwestern University of Finance and Economics.

Li, J. J. (2017). Analysis on the Restriction for Listed Companies' Illegitimate Profit Transfer Mechanism. Journal of Southwest University of Political Science \& Law, 1, 105-113. 
Li, J. J., \& Gan, S. D. (2015). Asset Injection of Directional Add-Issuance, Asset Evaluation and Interest Supply: The Empirical Data from China's Securities Market. Humanities \& Social Science Journal of Hainan University, 5, 38-45.

Li, S. N., Liu, Y. X., Chen, J. H. (2015). Does Fund Play Governance Roles in Chinese Listed Companies? An Analysis Based on the Sensitivity between CEO Forced Turnover and Corporate Performance. Nankai Business Review, 18(2), 4-14.

Mao, L., Wang, Z. J., Wang, L. L. (2012). Institutional Investors and Executive Compensation-A Study on Chinese Listed Companies. Journal of Management Science, 24(5), 99-110.

Niu, J. B., Wu, C., \& Li, S. N. (2013). Institutional Investor Types, Equity Characteristics and Voluntary Disclosure. Management Review, 25(3), 48-59.

Song, J. B., Gao, S. H., \& Guan, X. J. (2012). Institutional Ownership and Earnings Persistence of Listed Company Empirical Evidence from China's Share A Listed Company. China Soft Science, 2, 128-138.

Sun, G. G., Liu, S., \& Zhao, J. Y. (2015). Control of Largest Shareholder, Institutional Investors and Earnings Management. Nankai Business Review, 5, 75-84

Tang, J. R., \& Zhu, T. J. (2017). Research on Pyramid Shareholding Structures and Ultimate Controller's Tunneling Effect. Commercial Research, 5, 23-29.

Wang, J., \& Zhu, J. G. (2015). Fund Involvement in Corporate Governance: A Choice of Behavioral Logic and Pathway-A Case Study of Shanghai Jahwa and Gree Electric Appliances. China Industrial Economics, 5, 135-147.

Zhang, W. D., Huang, Y. S., Li, S. L., \& Yan, X. (2017). Information Asymmetry, R\&D Expenditure and Related Shareholders' Subscription of New Shares in Private Placement-Empirical Data from China Securities Market. Accounting Research, 1, 68-74.

Zhang, W. D., Liu, S. M., \& Huang, Y. S. (2017). Institutional Environment, Government Intervention, and Interest Supply in Asset Injection of Directional Add-Issuance-Empirical Data from Local Government Holding Companies. Jiangxi Social Sciences, 2, 63-74.

Zhang, W. D., Luo, G. M., \&Tao, Y. Y. (2016). Research on Shareholder's Wealth Effect of Employee Stock Option Plan in Listed Companies: Evidence from China's Stock Market. Journal of Beijing Technology and Business University (Social Sciences), 2, 61-70.

Zhang, Y., Yin, S. L., \& Liu, T. H. (2014). An Analysis of Foreign Strategic Investors and the Banks' Performance in China. Economic Review, 2, 139-149.

Zhou, X. S., \& Wang, L. (2017). Sponsors' Reputation, Earning Management in the Private Placement of Equity and Long-Run Performance. Review of Investment Studies, 5, 29-47.

\section{Note}

Note 1. In 2017, the CSRC made further amendments to the regulations regarding the sales of shares by institutional investors after private placements. It is stipulated that an institutional investor may sell no more than $50 \%$ of its shares obtained from a given private placement in 12 months following the lockup period.

\section{Copyrights}

Copyright for this article is retained by the author(s), with first publication rights granted to the journal.

This is an open-access article distributed under the terms and conditions of the Creative Commons Attribution license (http://creativecommons.org/licenses/by/4.0/). 